\title{
CERPEN FARUK "BUS KOTA” DALAM SEMIOTIK ROLAND BARTHES
}

\author{
Oleh: \\ Ken Widyatwati \\ Jurusan Sastra Indonesia Fakultas Ilmu Budaya Universitas Diponegoro \\ Jl. Prof. H. Soedarto, SH Tembalang Semarang 50275 \\ E-mail: kenwidyatwati@gmail.com
}

\begin{abstract}
Literature called beautiful if it contains the mandate, message, ideas and meanings that are useful for the readers. Short story "Bus Kota" (City Bus) containing the mandate, message, ideas and meanings that are useful to the reader. The mandate will be revealed by Roland Barthes' semiotic theory in the book S/Z. Literature has its own allure and text have accrued but not due to independence because of the difference in quality. Texts merge into a unity, or restore any text not as an individual but as a form of plurality. Literature as part of a social system is an expression of the author's sense of the outpouring of public life. Literary works can express themselves in the author's view the social and cultural changes in society because of the development of information technology and rapid. Technological developments and socio-cultural information can change in society so as to affect the psychology of the people. Society must have a thickness of faith not only for themselves, but to be able to maintain equanimity in the life of a pluralistic society.
\end{abstract}

Keywords: City Bus, information technology, social change culture

\section{PENDAHULUAN}

Sebuah cipta sastra bukan hasil dari apa yang disebut ilham tetapi juga hasil dari pemikiran dan kesadaran pengarangnya. Berdasarkan penelitian secara ilmiah diakui bahwa ilmu Sastra itu berdiri sendiri secara otonom disamping ilmu bahasa. Kesusastraan yang dijadikan penelitian adalah sastra sebagai peristiwa seni, bukan sebagai peristiwa bahasa. Disini bahasa hanya sebagai alat, yang penting adalah apa yang disampaikan bahasa itu. Bidang penelitian kesusastraan sebagai penelitian ilmiah harus ada sistematikanya, sehingga tidak memungkinkan timbul kesimpang siuran dalam cara penelitian tersebut. Sebuah cipta sastra bukanlah hasil dari apa yang disebut ilham tetapi adalah juga hasil dari pemikiran dan kesadaran pengarang.
Dengan penelitian secara ilmiah diakui bahwa ilmu sastra berdiri sendiri secara otonom disamping ilmu bahasa.

Penelitian bukan hanya sekedar untuk penelitian, akan tetapi dapat diambil manfaat timbal balik antara pengarang dengan peneliti dan penikmat sastra. Teori dan kritik sastra dapat memberikan dorongan dan meningkatkan daya apresiasi masyarakat dan penikmat karya sastra, sastrawan dapat mengambil manfaat dalam pengembangan diri pada proses penciptaan.

Selama ini tidak disangkal akan adanya bermacam pendekatan terhadap cipta sastra yang dalam segi-segi tertentu mendapat tekanan atau perhatian. Tetapi apakah hal ini dapat menjadi dasar ditemukannya penelitian secara bulat 
terhadap cipta sastra, maka perlu adanya patokan-patokan atau ukuran-ukuran sebagai syarat obyektif dalam bidang penelitian sastra.

Penelitian sastra hendaklah lebih dahulu dibedakan wilayah kehidupan kesustraan itu sendiri yaitu wilayah para sastrawan yang diisi dengan ciptaanciptaandan wilayah peneliti yang mengadakan penelitian tentang kesustraan. Hal ini tidak berarti bahwa sastrawan sebagai pencipta karya sastra tidak punya tempat dalam bidang penelitian, begitu juga sebaliknya seorang peneliti tidak berarti tidak mungkin menghasilkan sebuah karya sastra.

Penilaian kesusastraan mendasarkan perhitungannya pada nilai-nilai intrinsik dan ekstrinsik yang terdapat dalam sebuah karya sastra. Penelitian bukan hanya sekedar penelitian, akan tetapi dapat diambil manfaat timbal balik antara pengarang sebagai seorang sastrawan dengan peneliti dan penikmat karya sastra. Teori dan kritik sastra dapat memberikan dorongan dan meningkatkan daya apresiasi masyarakat penikmat karya sastra. Sastrawan akan dapat mengambil manfaat dalam pengembangan diri dalam bidang penciptaan.

Penelitian terhadap karya sastra selalu membutuhkan landasan teori, untuk mengungkap makna dibalik sebuah karya sastra. Salah satu terori yang dapat digunakan untuk mengungkap makna karya sastra adalah teori semiotik. Salah satu teori semiotik yang ada adalah teori semiotik yang dikembangkan oleh Barthes. Dalam penelitian ini peneliti akan meneliti sebuah cerpen yang berjudul "Bus Kota" karya Faruk HT dengan menerapkan langkahlangkah semiotik yang dipakai oleh Barthes.

Berdasarkan latar belakang di atas maka permasalahan dalam penelitian ini adalah bagaimanakah struktur dan makna cerpen "Bus Kota".

\section{SEMIOTIK ROLAND BARTHES}

Berdasarkan permasalahan di atas maka tujuan penelitian ini adalah mengungkap struktur dan makna dalam cerpen "Bus Kota” dengan teori semiotik.

Analisis sastra dimaksudkan untuk dapat memahami struktur cerita secara mendalam, tidak untuk merusak karya sastra yang sudah jadi. Analisis bukan sekedar menelaah karya sastra, tetapi dari analisis dapat diketahui makna apa yang terdapat dalam karya sastra. Karya sastra ditelaah berdasarkan karya sastra secara otonom. Bukan pertaliannya dengan benda-benda atau hal-hal diluar dunia yang menentukan nilai karya sastra, tetapi makna yang terdapat dalam karya sastra.Karya sastra disebut indah jika karya sastra itu mengandung amanat, pesan, ide dan makna yang berguna bagi pembacanya (Wellek, 1989).

Teori struktural dan semiotik dewasa ini merupakan salah satu teori kritik sastra yang baru, disamping teori estetika resepsi dan dekuntruksi. Akan tetapi teori ini belum banyak dimanfaatkan dalam bidang kritik sastra di Indonesia.

Adanya makna yang dapat dipahami dalam sebuah teks sastra menunjukkan keanekaragaman tanda sehingga menghasilkan makna dari teks. Hal ini, menyebabkan teks mempunyai bermacammacam makna.

Teks sastra bukan sesuatu yang stabil tetapi keserbamungkinan yaitu bahwa satu indikasi pemahaman makna teks sastra itu bergerak dan berubah maknanya sesuai yang menginterpretasi-kan sehingga pembaca yang satu dengan yang lain melahirkan perbedaan makna. Hal ini terjadi karena pengalaman dan latar belakang yang berbeda dari pembaca.

Karya sastra harus mempunyai daya pikat sendiri dan teks mempunyai kedudukan bukan karena kemandirian tetapi karena adanya perbedaan pada kualitas. Barthes menjelaskan teks sebagai suatu kebebedaan atau suatu kemandirian yaitu memaksa teks untuk bergabung kedalam suatu kebersamaan, atau merestorasi setiap 
teks bukan sebagai individual tetapi sebagai pluralitas.

Karya sastra merupakan sebuah struktur yang kompleks, karena itu untuk memhami karya sastra baik prosa maupun puisi harus dianalisis terlebih dahulu (Hill, 1996: 6). Namun sebuah analisis yang tidak tepat tidak akan mampu mengungkap makna dibalik karya sastra. Unsur-unsur sebuah karya sastra bukanlah bagian-bagian yang berdiri sendiri, tetapi bagian-bagian itu dipahami sebagai keseluruhan. Hal ini juga dikemukakan oleh Eliot dalam Sansom, (1960: 155). Karya sastra adalah struktur yang merupakan susunan keseluruhan yang utuh. Antara bagian-bagiannya saling erat berhubungan. Tiap unsur dalam situasi tertentu tidak mempunyai arti tersendiri melainkan artinya ditentukan oleh hubungannya dengan unsur-unsur yang lainnya yang terlibat dalam situasi itu. Makna penuh suatu satuan atau pengalaman dapat dipahami hanya jika terintegrasi kedalam struktur yang merupakan keseluruhan dalam kesatuan-kesatuan itu (Hawkes, 1979:18). Antara unsur-unsur struktur ada koherensi atau pertautan erat, unsur-unsur itu tidak otonom melainkan merupakan bagian dari situasi yang rumit dan dari hubungannya dengan bagiannya yang lain, unsur itu mendapat artinya (Culler, 1977: 70-71). Jadi untuk memahami sastra haruslah diperhatikan jalinan atau pertautan unsur-unsur sebagai bagian dari keseluruhan.

Untuk memahami sebuah karya sastra harus memperhatikan tanda-tanda, kodekode yang tertdapat dalam karya sastra tersebut. Hal ini juga dilakukan oleh Barthes dalam bukunya S/Z, yang mencoba mengungkapkan kode-kode yang ada dalam sebuah novel Perancis yang berjudul Sarassine agar dapat mengungkap makna dalam novel tersebut.

Barthes menggabungkan pendeka-tan struktural dengan pendekatan pragmatik: Pembaca dipandang sebagai penyingkap struktur karya sastra secara mutlak, dan peran pembaca mempunyai subyektifitas yang kuat, dan akhirnya pembaca serta peneliti sastra, menjadi pencipta makna yang daya ciptanya tidak kurang dari kreativitas pengarang.Manusia mempunyai lebih dari duapertiga pesan-pesan melalui tubuh, berupa tanda-tanda fisik berupa postur tubuh yang berbeda,isyarat tangan,ekspresi wajah (Morris,1979). Tanda-tanda tubuh umumnya memiliki fungsi sosial yang mengatur hubungan dirisendiri dengan orang lain. Tanda-tanda ini memastikan bahwa cara-cara orang berinteraksi dalam lingkungan budaya mereka dan dalam masyarakat supaya teratur dan lancar (Danesi,2010: 53).

Jaringan yang membangun sebuah teks karya sastra menurut Barthes (1972) didasari oleh lima kode. Kelima kode tersebut terdiri dari:

\section{Kode Hermeniutik (HER)}

Dalam kode ini dapat didaftar berbagai istilah dalam satu enigma yang dapat dibedakan, diisyaratkan, diformulasi-kan, sesuai pendapat pembaca.

2. Kode Semes (SEME)

Kode seme membantu untuk mengindikasikan seme-seme I pada teks dengan kata lain mencoba untuk mempertalikan seme dengan suatu karakter, atau menata seme-seme itu membentuk suatu pengelompokan tematik yang tunggal.

3. Kode Simbolik (SYM)

Kode ini merupakan tempat bagi multi valensi dan bagi reversibilitas, tugas utamanya selalu menunjukkan bahwa pada bagian ini dapat dimasuki dari sejumlah titik, yang membuat kedalaman dan kerahasiaan diplomatik, problematik.

4. Kode Proaretik (ACT)

Kode ini mengindikasikan (secara eksternal dan internal) untuk menunjukkan kepluralan makna yang terlekat didalamnya. Apa yang kita baca itu berdasarkan pengalaman atau hal yang kita pahami.

5. Kode Kultural (REF) 
Kode ini merupakan acuan pada suatu ilmu pengetahuan atau suatu tubuh pengetahuan, dalam membalikkan perhatian atasnya kita semata-mata mengindikasikan tipe pengetahuan (fisik, fisiologis, medis, psikologis, literer, historis, dsb) yang diacu, tanpa harus pergi terlalu jauh untuk mengkontruksi (merekontruksi) kebudayaan yang diekspresikannya.

Berdasarkan lima kode di atas peneliti akan mencoba untuk memahami dan menerapkannya pada analisis cerpen yang berjudul "Bis Kota” karya Faruk H.T. yang terdapat dalam kumpulan cerpen "Kartu Nama” yang diterbitkan oleh Pustaka Pelajar.

Langkah-langkah penelitian ini dibuat dengan maksud untuk memudahkan dan memberikan arahan jalannya penelitian, sehingga dapat berguna sebagai tuntunan bagi peneliti dalam menyusun dan melaksanakan penelitian secara terencana dan sistematis. Uraian berikut menjelaskan langkah-langkah penelitian yang akan dilakukan.

Data adalah informasi atau keterangan mengenai segala sesuatu yang berkaitan dengan penelitian.Data dalam penelitian ini terdiri dari data primer dan data sekunder. Data-data dalam penelitian ini diperoleh dari studi pustaka. Sumber data primer adalah sumber data yang diperoleh secara langsung pada saat penelitian. Sumber data primer dalam penelitian ini adalah cerpen "Bis Kota” karya Faruk H.T. Sumber data sekunder adalah sumber data yang diperoleh dari buku-buku, makalah, majalah dan koran yang berkaitan dengan obyek kajian. Data sekunder ini digunakan untuk pembandingan dan memperkaya data penelitian.

Berdasarkan data yang ada maka dilanjutkan dengan analisis data penelitian, selanjutnya dilakukan penarikan kesimpulan penelitian. Analisis data menggunakan teori semiotika Roland Barthes untuk mengungkap struktur dan makna cerpen "Bus Kota".

\section{STRUKTUR DAN MAKNA CERPEN "BUS KOTA"}

Penyajian hasil analisis data pada penelitian ini adalah deskripsi. Deskripsi adalah menyajikan hasil analisis data dengan cara menjelaskan dan menguraikan atau mendeskripsikan obyek penelitian seakanakan ada dihadapan pembaca.

Untuk memahami sebuah karya sastra harus memperhatikan tanda-tanda, kodekode yang tertdapat dalam karya sastra sebagai langakah awal untuk memahaminya.

Hal ini juga dilakukan oleh Roland Barthes dalam bukunya S/Z, yang mencoba mengungkapkan kode-kode yang ada dalam sebuah novel Perancis yang berjudul Sarassine. Cara Roland Barthes ini akan peneliti aplikasikan dalam analisis cerpen "Bus Kota” berikut ini.

Judul Bus Kota* berdasarkan judul ini dapat digambarkan sebagai kode Hermeniutik (HER) yaitu segala satuan yang fungsinya adalah meng-artikulasikan segala pertanyaan, respon dan berbagai peristiwa yang dapat merumuskan pertanyaan dan menunda jawaban, yang membentuk suatu enigma dan membawa pada solusi titik dengan demikian judul bis kota merupakan langkah pertama dalam sebuah urutan (HER enigma 1:cerita mengandung pertanyaan). Apakah Bus Kota itu?

Kata Bus Kota** menimbulkan arti konotasi tambahan yaitu kekerasan (kemaskulinan), kemaskulinan ini merupakan suatu penanda yang akan terjadi dibeberapa tempat dalam teks. Dan merupakan perubahan unsur yang dapat berkombinasi dengan unsur-unsur serupa lainnya untuk menciptakan suatu karakter, bentuk-bentuk dan simbol-simbol. Setiap unit yang disebut ini akan menjadi suatu penanda, dan penanda yang satu ini mempunyai tipe yang khusus, karena kemaskulinan mempunyai arti keras, kuat. Atau mungkin akan kita sebut sebagai sebuah seme karena secara semantik seme 
adalah sebuah unit penanda, dan penandaan setiap waktu merupakan tafsiran sebagai penanda konotatif yang menunjukkan didalam satu leksia (SEM: Maskulin, Kekerasan).

Bus Kota adalah lambang kehidupan dunia dimana terjadi banyak kemungkinan dari yang bersifat baik sampai yang kasar. Artinya dalam kehidupan dapat ditemui kebahagiaan misal: bertemu teman lama, kenalan baru atau sesuatu yang sangat menakutkan misal: kecopetan, dibajak, perkosaan, perampokan. Ketakutan ini bisa dilihat dari tokoh Aku. Ketakutan tokoh Aku dapat diuraikan sebagai berikut.

Aku baru saja datang dari udik, pedalaman Kalimantan* suatu pernyataan yang terbawa dari kata udik yang membawa ke seme terpencil, jauh, karena kata udik menggambarkan suatu tempat yang jauh. Terpencil, jauh berkonotasi sebagai tempat tinggal manusia (orang-orang) yang berada jauh dari perkotaan dan kebudayaan kota (modern). Pedalaman Kalimantan mengacu suatu tempat, melalui suatu perbandingan, tentang suatu tempat yang jauh, primitif dan mungkin juga terbelakang (SEM: terpencil, asing).

Udik atau orang kampung yang baru saja datang ke kota akan merasa canggung dan takut. Ketakutan ini muncul karena merasa asing dan tidak mengenal lingkungan.

Ketika memasuki pintu kendaraan umum itu* Hal ini merupakan perkembangan dari antitesis yang biasanya meliputi suatu eksposisi dari setiap bagiannya masing-masing. Istilah ketiga dimungkinkan sebagi sebuah penyajian bersama atau gabungan, kita dapat merujuknya sebagai suatu penunjuk konjungsi yang bersifat fisik yaitu suatu antitesis: tempat sempit. Kendaraan umum menunjukkan suatu tempat yang terbatas yang diisi oleh banyak orang (SYM. Antitesis: Sempit, Terjepit). Bus Kota adalah penggambaran tempat yang sempit, dan terjepit karena bus kota adalah kendaraan umum yang paling diminati masyarakat karena murah sehingga bus kota selalu penuh sesak dengan penumpang.

Setelah beberapa kali naik kendaraanitu*, perasaan risih dan berangsurangsur sirna** REF. Kode kronologis (beberapa kali) di sini keberanian mulai muncul terlihat dari perasaan yang risih dan rasa jijik serta bergidik yang berangsurangsur hilang. Perasaan ini bisa dimasukkan dalam suati enigma (apa penyebabnya?), serta leksia dianggap sebagai suatu kode hermeniutik dengan menunjukkan pada suatu obyek atau subyek, atau jika kita menyukainya dapat kita keluarkan dengan apa adanya (HER. Enigma 2: Obyek utama). Ketika orang pertama kali naik bus kota akan merasa canggung, takut tetapi setelah berkali-kali naik akan terbiasa dengan kedaan bus kota.

Aku mencoba mencari tempat yang sedikit lapang, namun gagal* Aku mencoba mencari tempat yang sedikit lapang. Ini dapat diartikan aku sedang berusaha dan bentuk pertama dari antitesis (tempat, ruang) dan menurut kode: dapat dikatakan sebagai tempat yang longgar (SYM. Antitesis: Kelonggaran). Seseorang yang merasa terjepit ditengah keramaian akan berusaha untuk mencari tempat yang longgar dan nyaman supaya tidak merasa terhimpit dan terjepit.

Lalu kututup seluruh sebagian bagian tubuhku. Sekarang aku memakai jilbab* Disini dapat kita lihat adanya perpindahan dari suatu term antitesis (tidak memakai jilbab, berpakaian biasa) ke hal yang lain (berjilbab) hal ini menunjukkan adanya pergerakan batin, sehingga yang terjadi bukan suatu kelincahan wacana tetapi (bagian dari kode retorikal) tetapi merupakan suatu aksi fisikal dari konjungsi (bagian dari tingkat/level simbolik) (SYM. Antitesis: pergerakan batin).

Keterjepitan seseorang ditengah masyarakat yang tidak baik, selalu menumbuhkan keinginan melindungi diri dari hal yang buruk. Perlindungan itu bisa diperoleh dari kekuatan iman dan agama. Disini digambarkan sang tokoh memakai 
jilbab untuk membentengi diri dari pengaruh tidak baik yang ada disekitarnya. Hal ini menggambarkan pergerakan batin tokoh.

Jilbab yang panjang dan menutup seluruh aurat seakan menjadi sebuah dinding beton tebal* Perkembangan sebuah antitesis biasanya merupakan keterangan yang meliputi eksposisi dari setiap bagiannya. Ini dimungkinkan sebagai suatu penyajian bersama. Istilah ini bias menjadi benar-benar retorikal jika kita memperhatikannya untuk menunjukkan antitesis. Tetapi, hal ini juga dapat dilihat secara literal, jika kita menekankan pada konjungsi fisikal dari antitesis: disini diartikan sebagai suatu tempat persembunyian/tempat yang tersembunyi, yaitu baju yang menutupi atau menyembunyikan semua aurat dengan sangat rapat (SYM.Antitesis: Tersembunyi, tertutup).

Jilbab disini menggambarkan sifat tokoh mengalami pergerakan dari yang terbuka dalam pergaulan atau bebas dalam pergaulan menjadi membatasi diri dari pergaulan yang tidak baik. Tokoh membetengi diri dari pergaulan bebas dengan lebih bertakwa dan menjalankan agama.

Berpuluh-puluh bis kota* Secara nyata dapat ditunjukkan sebagai suatu saat dialami oleh seseorang yang ada dalam tekanan batin (mental), gambaran ini mengkonotasikan sebagai keadaan batin seseorang yang berada dalam goncangan jiwa (REF. Psikologi Kejiwaan: Tekanan Batin).Berbagai pengalaman hidup akan membuat tokoh mengalami tekanan bathin. Hal ini terjadi karena dalam masyarakat (Bus Kota) akan banyak terjadi ketimpangan.

Besoknya bulat keputusanku untuk pulang* Hal ini menunjukkan adanya implikasi dari beberapa peristiwa yang membawa pada bagian akhir. (Aku putuskan untuk pulang). Urutan semacam ini merupakan implikasi dari sebuah logika dalam kebiasaan manusia. Atau kemungkinan secara rasional menentukan hasil atau tindakan-tindakan/aksi dan dapat dikatakan sebagai kode aksi dan sebagai suatu kebiasaan proaresis (ada dalam cerita, wacana, karakter yang menentukan aksi). Kode ini disebut kode prorektik (ACT). Hal ini merupakan tanggapan atau tindakan yang dilakukan untuk menghindar dari masalah, dan kembali (pulang) untuk mencari perlindungan dan ketentraman (ACT. Kembali: Mencari perlindungan, ketentraman).Pulang membuat tokoh tenang karena pulang berarti mendapat perlindungan, dari keluarga atau masyarakat yang telah dikenal.

Kembali ke kampung* Ketentraman ditransformasikan sebagai kampung (tempat yang tenang dan jauh dari keramaian), Seme tentang kampung ini mengkonotasikan suatu kehidupan yang masih dalam keadaan yang alami dan sangat terhjaga keasliannya, yang kemudian membentuk suatu leksia dan kode semes yang dapat diartikan sebagai suatu ketenangan batin (SEM: Ketenangan, ketentraman).Kampung adalah penanda sepi,tentram jauh dari keramaian dan hal-hal yang tidak baik.

Di kampung kami pun sudah berkeliaran bis-bis kota. Persis di kota ini* Bis-bis kota disini dapat diartikan sebagi suatu kejahatan, kebohongan, keduniawian (REF. Psikologi Sosial). Bis kota (kejahatan, kemunafikan, kekerasan)** Disini dapat kita temukan syarat-syarat dari dua term kode hermeniutik, yaitu adanya, ada sebuah tekateki dan jawaban yang harus ditunda: karena wacana ini menggerakkan perpindahan bisbis dari kota ke daerah kampung (pedalaman). Sehingga dari hal ini kita mengetahui jawaban dari teka-teki tersebut yaitu apa yang dimaksud dengan bis kota itu. Walaupun sampai akhir tidak ada cerita yang mengungkapkan. (HER. Enigma 3: Jawaban yang tertunda).

Kampung ternyata tidak lagi tentram karena tokoh melihat banyak bus kota, hal ini merupakan penanda bahwa di kampung tidak lagi tentram, nyaman, sepi, tetapi sudah berubah menjadi ramai, liar dan menakutkan. 
Hampir setiap malam aku diganggu mimpi buruk yang bahkan lebih mengerikan dari kenyataan yang aku alami* Hal ini merupakan pernyataan yang menunjukkan suatu tekanan batin yang dialami seseorang, gambaran yang jelas ini menunjukkan atau dapat dikatakan mengkonotasikan keadaan batin seseorang yang sedang mengalami depresi atau tekanan batin yang menimbulkan ketakutan, sehingga sampai halusinasinya terekam dalam mimpi (REF. Psikologi Kejiwaan: Depresi).

Mimpi buruk merupakan simbol terjadinya pertentangan bathin dalam diri tokoh, mimpi buruk merupakan penanda keterpurukan tokoh.

Sebagai perempuan aku merasa terganggu olehnya* Kata perempuan menunjukkan konotasi feminitas (kelemahan, kelembutan) feminitas ini merupakan suatu penanda dalam teks. Dan merupakan perubahan unsur-unsur lainnya untuk menciptakan suatu karakter, bentukbentuk dan simbol-simbol. Setiap unit yang kita sebut ini akan menjadi suatu penanda, dan penanda ini mempunyai tipe yang khusus, karena feminitas mempunyai arti yang biasa dari istilah itu. Atau dapat kita sebut sebagai sebuah seme secara semantik seme adalah sebuah unit penenda, dan penanda setiap waktu menunjukkan tafsiran sebagai penanda konotatif yang menunjukkan dalam satu leksia (SEM. Feminim, Kelemahan).

Tatapan mereka seperti merayapi sekujur tubuhku, rambutku, mataku, hidungku, bibirku, dadaku, lipatan pahaku, bibirku, lipatan-lipatan rok yang ada diantara dua pahaku, lutut bahkan kakiku. Aku bergidik. Ingin aku menarik kembali langkahku, turun dan berjalan kaki saja*. Hal ini menunjukkan gambaran seorang wanita muda, atau dapat dikatakan merujuk ke suatu seme penanda, dimana penanda ini merupakan sebuah leksia. (SEM: Wanita Muda).** SEM: Vegetalitas (kehidupan oraganik)*** Wanita muda adalah suatu tingkatan perubahan dari seseorang anakanak menjadi seorang wanita (remaja) yang pasif dan takut dimasuki oleh tatapan lakilaki. Disini situasi simbolisnya menunjukkan ketidak-mampuan dan ketakutan. Ingin aku menarik kembali lanngkahku, turun dan berjalan kaki saja. Kalimat ini menunjukkan adanya suatu penanda yang mengandung suatu konotasi tambahan yang artinya ketidakberanian, atau dapat juga dikatakan sebagai suatu penanda seme, karena secara semantik seme berarti satuan unit penanda yang ada atau dapat dimasukkan dalam satu leksia (SEM: Ketakutan, ketidak beranian). Tatapan mata mereka seperti merayapi sekujur tubuhku* Term ini menunjukkan suatu perasaan yang sangat ngeri/menakutkan, ia memerlukan suatu perlindungan atau pertolongan dari ketakutan yang dialaminya. Ia memerlukan vegetalitas yang berpengaruh yang dapat mengembalikan atau mempersatukan keberaniannya, paradigma ini mengukuhkan dirinya sendiri seorang wanita yang membutuhkan pengendalian diri tetapi dengan jalan menunjukkan peranan simbolis pada dirinya sendiri. Disini akan menempatkan ia dalam posisi yang pasif dari suatu subyek yang didominasi (SYM. Wanita-Lemah).

Perempuan, adalah simbol kelembutan, kelemahan. Perempuan adalah seseorang yang tercipta beda dengan lakilaki, apalagi ditengah dominasi kehidupan laki-laki.

Aku berdiri, berhimpitan dengan banyak orang yang semuanya tak kukenal* Suatu pernyataan yang terbawa dari kata ' 'tak kukenal', yang membawa kita kesana keterasingan karena tak kukenal (semuanya) menggambarkan suatu tempat yang terasing. Terasing menggambarkan suatu lingkungan kehidupan yang menyakitkan yang artinya banyak orang disekitar kita, tetapi tidak ada satupun yang kita kenal apalagi kita ajak untuk berkomunikasi. (SEM. Keterasingan).

Aku terpana* Pernyataan ini menunjukkan suatu keadaan dimana ia menjadi kaget, mungkin juga tak percaya atau penuh keheranan. Sehingga kata "terpana" dapat diartikan sebagai suatu 
keadaan yang tak terduga, yang sulit untuk diterima (dipercaya). Dan kata ini juga dapat diartikan sebagai suatu kode atau penanda seme, yang mengandung suatu konotasi tambahan (yang lain) yang diartikan sebagai ketidakpercayaan (terhadap suatu hal yang dihadapi atau suatu kenyataan yang tidak diduga sebelumnya). Satuan unit ini penanda seme ini juga dapat dimasukkan dalam satu penanda laksia (SEM. Kaget, tidak percaya). Ketidakberdayaan tokoh menimbulkan rasa tidak percaya diri dan merasa terasing dalam kehidupan masyarakat. Berdasarkan uraian di atas maka dapat digambarkan perubahan psikologis tokoh aku.

Aku seorang perempuan dari kampung pergi dan tinggal di kota dimana perkembangan teknologi informasi sangat pesat, membuat tokoh aku merasa terasing dan ketakutan. Ketakutan ini menyebabkan tokoh aku pulang ke kampung untuk mencari kenyamanan hidup, tetapi sesampai di kampung perkembangan teknologi dan informasi telah mengubah kampungnya menjadi kota modern. Tokoh aku mengalami depresi karena ketaklutan.

\section{SIMPULAN}

Dari analisis yang telah dilakukan terhadap Cerpen "Bus Kota" diperoleh kesimpulan yaitu: karya sastra sebagai bagian dari suatu sistem sosial merupakan ekspresi curahan rasa pengarang dalam kehidupan bermasyarakat. Karya sastra dapat mengekspresikan diri pengarang dalam melihat perubahan sosial budaya dalam masyarakat karena adanya perkembangan teknologi dan informasi yang pesat. Perkembangan teknologi dan informasi dapat merubah sosial budaya dalam masyarakat sehingga dapat mempengaruhi psikologi masyarakat. Masyarakat harus mempunyai ketebalan iman bukan hanya untuk sendiri, melainkan untuk dapat mempertahankan keseimbangan batin dalam kehidupan masyarakat yang plural.

\section{DAFTAR PUSTAKA}

Abramns, M.H.1972.The Mirror and The Lamp. England. Oxford University Presss.

Barthes, Roland.1972.S/Z.London: Cape Press.

Danesi, Marcell. 2010. Pesan Tanda dan Makna. Yogyakarta: Jalasutra.
Teeuw, A.1984. Sastra dan Ilmu Sastra. Jakarta. Pustaka Jaya.

Wellek, Rene dan Austin Warren.1989. Teori Kesusastraan. Jakarta: Gramedia. 